Fifth International Conference on Sustainable Construction Materials and

Technologies. http://www.claisse.info/Proceedings.htm

\title{
THE EFFECT OF USING BASIC OXYGEN SLAG WITH BY- PRODUCT AND NON-HAZARD WASTE MATERIALS TO PRODUCE PAVING BLOCKS
}

\section{Ghassan Jalull ${ }^{1}$ and Eshmaiel Ganjian ${ }^{2}$}

${ }^{1}$ Part time visiting research fellow in School of Energy, Construction and Environment, Faculty of Engineering, Environment \& Computing, Coventry University, Coventry, and Lecturer in Department of Civil Engineering, Faculty of Engineering, Az Zawiyah University, Az Zawiyah, Libya. < ghassan131973@yahoo.com>

${ }^{2}$ Professor of Civil Engineering Materials, Built \& Natural Environment Research Centre, School of Energy, Construction and Environment, Coventry University, Coventry, CV1 2JH. $<$ E.ganjian@Coventry.ac.uk>

\begin{abstract}
The production of Portland cement has significant adverse effects on the environment due to the emission of carbon dioxide. Therefore reduction of Portland cement content will benefit the carbon footprint of concrete products.

The use of waste and by-product materials, such as basic oxygen slag (BOS), ground granulated blast furnance (GGBS), run-of-station ash (ROSA), plasterboard gypsum (PG) and cement bypass dust (BPD) for the production of paving blocks is investigated. The combinations of binary and ternary blends in different mixes are considered. The split tensile strength of paving blocks specimens, verified that a cementitious mix containing BOS up to $70 \%$, ROSA up to $35 \%$, GGBS up to $40 \%$, BPD up to $10 \%$ and PG up to $5 \%$ by weight can replace Portland cement by $80 \%$ without having any substantial impact on the strength of the paving blocks produced in accordance with BS EN 1338:2003.
\end{abstract}

Keywords: Paving blocks, basic oxygen slag, waste minerals, split tensile strength.

\section{INTRODUCTION}

Pre-cast paving blocks manufactured using cementitious paste are widely used for various purposes including landscaping with blocks of different shapes and sizes. Paving blocks offer a hard surface upon which it is easy to walk on but they also have a long life when in use. This means that they can be useful for heavy duty purposes, such as in car parks, bus terminals and 
at bus stops as well as in petrol stations, on roundabouts, in industrial estates and for other uses. It is their capacity to cope with substantial loads as well as offering resistance to those forces that might otherwise shear off or damage the surface that makes them useful across such a wide area.

Beaty and Raymond, (1995) claim that using concrete paving blocks provides many advantages, such as ease of maintenance and repair and the provision of easy access to underground utilities. They are also available in colours and shapes that are both attractive and functional and these qualities account for the wide use given to them by contractors and engineers.

Almost all relevant civil engineering applications make use of Portland cement as an essential material and in 2009 it was estimated that the annual production of cement worldwide exceeded 3 billion tonnes with this figure increasing further during 2010 (Oss, 2003). In order to manufacture paving blocks, it is usual for a minimum of $210 \mathrm{~kg}$ of cement per $\mathrm{m}^{3}$ to be used. However, when Portland cement is produced it impacts negatively on the environment to a significant extent due to the carbon dioxide emissions (Ganjian et al. 2015). Cement production accounts for roughly $8 \%$ of global $\mathrm{CO}_{2}$ emissions (Olivier et al.2012).

According to Turanli et al. (2004) energy plays a very important part in the manufacture of Portland cement, "Portland cement manufacturing is an energy-intensive process in which approximately 4 GJ of energy/tonne, mostly obtained from the burning of fossil fuels, is consumed".

However, reduction of waste from industrial processes has become more complex and costly. On the other hand, there are stringent laws relating to the environment and a limit has been put on sites where waste can be disposed of. Therefore, government policies in all regions of the world are used to pro-actively promote the use of non-hazardous waste and products through construction regulations.

Nowadays, mineral additives are attracting a great deal of attention as materials that contribute to the improvement of specific properties of concrete, as well as decreasing the carbon dioxide emissions and energy generated in making the cement.

Since 1970 researchers have been engaged in attempts to partially replace Portland cement with other suitable materials. Some pozzolans, limestone and metakaolin are possible materials which occur naturally; others such as fly ash and steel slag are produced by various metallurgy 
processes, with silica and other materials being the by-products of various industries (Limbachiya et al. 2006). If it is possible to make use of existing waste materials, this would lead to the environmental impact being largely reduced as well as natural raw materials being preserved. This will mean that the overall energy required for the production of a cementitious material will be reduced, thus reducing the carbon dioxide emissions (Ganjian and SadeghiPouya, 2009).

This research aims to explore the possibility of using a mixture of different waste pozzolans to make paving blocks, and to reduce the percentage of Portland cement in the mixture. Moreover, this should make possible a reduction in the waste materials in order to reduce their effect on the environment.

\section{MATERIALS USED IN THIS RESEARCH}

\subsection{Basic oxygen slag (BOS)}

Basic oxygen slag otherwise known as steel slag dust is a by-product generated during the conversion of iron into steel. During the current production of steel it is inevitable that basic oxygen steel slag will be produced (Ganjian et al. 2015). with nearly 150kg resulting from the manufacture of each tonne of steel. In 2006, the United States had an iron and steel slag output of approximately 21.5 million tonnes, with $40 \%$ being classified as steel slag (Oss, 2003). Where possible the use of basic oxygen steel slag is favoured in US production, not only because this prevents unpleasant slag accumulates being produced but also because it means there is less need for finite primary materials to be used. The basic oxygen slag for this research was obtained from the Tata Steel plant at Scunthorpe

\subsection{Grand Granulated Blast-furnance slag (GGBS)}

Ground granulated blast-furnace slag 'GGBS' is a cement substitute, manufactured from a byproduct of the iron-making industry. GGBS essentially consists of silicates and alumina silicates of calcium and other bases that are developed in a molten condition simultaneously with iron in a blast-furnace. The chemical composition of oxides in GGBS is similar to that of Portland cement but the proportion varies (Dubey et al.2012). Using GGBS with Concrete has many advantages, including improved durability, workability and economic benefits (American Concrete Institute, 2003).

The Ground Granulated blast-furnace slag (GGBS) was obtained from Civil and Marine, a part of Hanson UK. The material complies with BS EN 15167-2:2006. 


\subsection{Run-of-station ash (ROSA)}

For this research dry run-off-station ash has been obtained from Rugby Ash. In this case, the run-off-station ash is derived from a power station with an average particle size of 20 micron. Run-off-station ash is an unclassified fly ash collected from the chimney stacks of power stations. It is pozzolanic and reacts with calcium hydroxide and alkalis to form cementitious compounds, such as calcium silicate/aluminate hydrates.

\subsection{Plasterboard gypsum (PG)}

In this research the crushed plasterboard gypsum waste from demolition and construction sites was received from Lafarge plasterboard recycling plant in Bristol. Plasterboard used in the construction and repair of buildings as a facing for walls and ceiling, also it is used for forming certain structures, for instance barriers. "Plasterboard waste can arise on construction sites for a number of reasons, including wasteful design, off-cuts generated during installation, damaged boards, and over-ordering (Dunster, 2008). Crushed plasterboard gypsum waste from different sources, such as construction and demolition sites, was recycled and classified carefully to avoid some contaminants such as paper and glass.

The big pieces of paper and other contaminations were separated by using a series of sieves before the gypsum was crushed using a metal tamper. Plasterboard was then ground, sieved and conditioned to form a powder. The analysis of the particle size of the gypsum was made using a Malvern Mastersize 2000 laser analyser with an accuracy of $\pm 1 \%$. As a result, the particle size was found to be between $1 \mu \mathrm{m}$ and $1 \mathrm{~mm}$ in diameter, and mostly $>300 \mu \mathrm{m}$ (Ganjian and Sadeghi-Pouya, 2009).

\subsection{Cement by-Pass dust (BPD)}

By-Pass Dust (BPD) is collected from the kiln bypass. The bypass is used to bleed off volatile materials that would otherwise re-circulate around the kiln and pre-heater system (condensing in cooler parts of the kiln causing blockages) or eventually end up in the cement clinker. The most important consideration for BPD is the temperature, BPD is taken out from part of the kiln where the temperature is about $1000^{\circ} \mathrm{C}$. As a result, BPD contains more cement bound phases (Jalull et al. 2014). The BPD was provided in a powder form. However, the average size of fine particles is about $10 \mu \mathrm{m}$ for the BPD, and the maximum particle size is 200 micron. 
BPD from a local cement works, Castle Cement (Heidelberg cement group in Rugby, UK) was obtained for this research.

\subsection{Ordinary Portland cement (OPC):}

The cement used for this research was CEM1 cement and it complied with the European standard BSEN-197 (2011).

\section{EXPERIMENTAL WORK AND MIX PROPORTIONS}

In this research the aim was to find out the best way to achieve good consistent test result for paving blocks made in the laboratory. A compression machine was used to fully compact the materials in a single layer with $150 \mathrm{kN}$ of load.

A mould collar of $75 \mathrm{~mm}$ high was used to retain the material within the mould. Paving blocks made were $190 \times 100 \mathrm{~mm}$ cross section and either $75 \mathrm{~mm}$ thick, or $80 \mathrm{~mm}$ thick. Once cast the specimens were covered with a polythene sheet so that there would be no loss of water. On the next day all samples were de-moulded and then stored in curing chambers at a constant air temperature of $22 \pm 2$ degrees $\mathrm{C}$ and $98 \%$ relative humidity until they were to be tested.

BS EN 1338: 2003 was used to determine the split tensile strength of the paving blocks and the tensile force was applied along the longest side of the specimen block. Prior to the test the block specimen was located in the split tensile steel frame, using fibreboard strips on the top and bottom of the specimen to provide packing. Contact was made between the platens of the loading machine and the top and bottom of the steel plates of the testing frame, before the load was slowly applied at a rate of $0.05 \pm 0.01 \mathrm{MPa} / \mathrm{s}$ until the point of failure. At this point the test was stopped and the specimen divided into two halves by tensile force. A record was made of the failure load and the split tensile strength was calculated in MPa according to BS EN 1338: 2003.

The standard requires a minimum split tensile strength of $3.6 \mathrm{MPa}$ for paving blocks in order to be acceptable by the industry. Blocks were tested after 14 and 28 days.

The mix designed to be used in this research aimed to obtain the highest split tensile strength of binary and ternary mixtures. Five different groups of mixes were designed and tested and the split tensile strength on paving blocks specimens was determined. The water content for all groups of mixes was constant at 15 percent. 


\section{MIX DESIGNS FOR PASTE PAVING BLOCKS}

The mix design of all paste made are shown in table 1. Five different groups of paste blocks were made.

Table 1. Mixes of paste giving percentage by weight:

\begin{tabular}{|c|c|c|c|c|c|c|c|}
\hline Mix code & $\begin{array}{c}\text { OPC } \\
(\%)\end{array}$ & $\begin{array}{c}\text { BOS } \\
(\%)\end{array}$ & $\begin{array}{c}\text { ROSA } \\
(\%)\end{array}$ & $\begin{array}{c}\text { GGBS } \\
(\%)\end{array}$ & $\begin{array}{l}\text { PG } \\
(\%)\end{array}$ & $\begin{array}{l}\text { BPD } \\
(\%)\end{array}$ & $\mathrm{W} / \mathrm{C}$ \\
\hline OPC40/BOS30/GGBS30 & 40 & 35 & - & 35 & - & - & 0.15 \\
\hline OPC30/BOS30/GGBS40 & 30 & 30 & - & 40 & - & - & 0.15 \\
\hline OPC30/BOS40/GGBS30 & 30 & 40 & - & 30 & - & - & 0.15 \\
\hline OPC30/BOS35/GGBS35 & 30 & 35 & - & 35 & - & - & 0.15 \\
\hline OPC20/BOS40/GGBS40 & 20 & 40 & - & 40 & - & - & 0.15 \\
\hline OPC20/BOS50/GGBS30 & 20 & 50 & - & 30 & - & - & 0.15 \\
\hline OPC30/BOS65/PG5 & 30 & 65 & - & - & 5 & - & 0.15 \\
\hline OPC40/BOS55/PG5 & 40 & 55 & - & - & 5 & - & 0.15 \\
\hline OPC50/BOS45/PG5 & 50 & 45 & - & - & 5 & - & 0.15 \\
\hline OPC60/BOS35/PG5 & 60 & 35 & - & - & 5 & - & 0.15 \\
\hline OPC70/BOS25/PG5 & 70 & 25 & - & - & 5 & - & 0.15 \\
\hline OPC50/BOS47/PG3 & 50 & 47 & - & - & 3 & - & 0.15 \\
\hline OPC30/BOS35/ROSA35 & 30 & 35 & 35 & - & - & - & 0.15 \\
\hline OPC40/BOS30/ROSA30 & 40 & 30 & 30 & - & - & - & 0.15 \\
\hline OPC50/BOS25/ROSA25 & 50 & 25 & 25 & - & - & - & 0.15 \\
\hline OPC50/BOS30/ROSA20 & 50 & 30 & 20 & - & - & - & 0.15 \\
\hline OPC52/BOS18/ROSA30 & 52 & 18 & 30 & - & - & - & 0.15 \\
\hline OPC60/BOS20/ROSA20 & 60 & 20 & 20 & - & - & - & 0.15 \\
\hline OPC70/BOS15/ROSA 15 & 70 & 15 & 15 & - & - & - & 0.15 \\
\hline OPC70/BOS30 & 70 & 30 & - & - & - & - & 0.15 \\
\hline OPC60/BOS40 & 60 & 40 & - & - & - & - & 0.15 \\
\hline OPC50/BOS50 & 50 & 50 & - & - & - & - & 0.15 \\
\hline OPC40/BOS60 & 40 & 60 & - & - & - & - & 0.15 \\
\hline OPC30/BOS70 & 30 & 70 & - & - & - & - & 0.15 \\
\hline OPC80/BOS10/BPD10 & 80 & 10 & - & - & - & 10 & 0.15 \\
\hline OPC70/BOS20/BPD10 & 70 & 20 & - & - & - & 10 & 0.15 \\
\hline OPC60/BOS33/BPD7 & 60 & 33 & - & - & - & 7 & 0.15 \\
\hline OPC50/BOS45/BPD5 & 50 & 45 & - & - & - & 5 & 0.15 \\
\hline OPC40/BOS55/BPD5 & 40 & 55 & - & - & - & 5 & 0.15 \\
\hline
\end{tabular}

\section{RESULTS}

\subsection{Chemical analysis of materials}

Chemical analysis of the raw materials was carried out using XRF method.

These are shown in table 2 . 
Table 2. Chemical content of OPC, BOS, ROSA, PG and PBD used.

\begin{tabular}{|l|c|c|c|c|c|c|}
\hline Sample & $\begin{array}{c}\text { OPC } \\
(\%)\end{array}$ & $\begin{array}{c}\text { BOS } \\
(\%)\end{array}$ & $\begin{array}{c}\text { ROSA } \\
(\%)\end{array}$ & $\begin{array}{c}\text { PG } \\
(\%)\end{array}$ & $\begin{array}{c}\text { PBD } \\
(\%)\end{array}$ & $\begin{array}{c}\text { GGBS } \\
(\%)\end{array}$ \\
\hline $\mathrm{SiO} 2$ & 20.00 & 11.43 & 45.91 & 2.43 & 21.86 & 37.28 \\
\hline $\mathrm{TiO} 2$ & - & 0.39 & 1.41 & 0.03 & 0.29 & 0.58 \\
\hline $\mathrm{Al} 2 \mathrm{O} 3$ & 6.00 & 1.60 & 26.51 & 0.81 & 3.85 & 10.79 \\
\hline $\mathrm{Fe} 2 \mathrm{O} 3$ & 3.00 & 28.24 & 5.23 & 0.36 & 2.57 & 0.43 \\
\hline $\mathrm{MnO}$ & - & 4.35 & 0.08 & $<0.01$ & 0.02 & 0.68 \\
\hline $\mathrm{MgO}$ & 1.50 & 8.27 & 2.13 & 0.40 & 1.13 & 8.83 \\
\hline $\mathrm{CaO}$ & 63.00 & 41.29 & 6.88 & 37.30 & 53.40 & 40.12 \\
\hline $\mathrm{Na} 2 \mathrm{O}$ & 1.00 & 0.02 & 0.61 & 0.03 & 0.41 & 0.27 \\
\hline $\mathrm{K} 2 \mathrm{O}$ & 1.00 & 0.02 & 1.35 & 0.24 & 3.64 & 0.37 \\
\hline $\mathrm{P} 2 \mathrm{O} 5$ & - & 1.48 & 0.98 & 0.02 & 0.08 & $<0.05$ \\
\hline $\mathrm{SO} 3$ & 2.00 & 0.44 & 1.37 & 53.07 & 7.10 & 0.15 \\
\hline $\mathrm{Lol}$ & 0.50 & 3.12 & 7.11 & 4.09 & 5.64 & 1.03 \\
\hline
\end{tabular}

\subsection{Chemical analysis of mixtures}

Four sets of pastes were studied and the chemical analysis was determined using XRF method, the results are shown in table 3.

Table 3. Chemical analysis of the materials, carried out using XRF method

\begin{tabular}{|l|c|c|c|c|c|}
\hline Sample oxides & $\begin{array}{c}\text { OPC/ } \\
\text { BOS / } \\
\text { GGBS }\end{array}$ & $\begin{array}{c}\text { OPC/ } \\
\text { BOS/ } \\
\text { PG }\end{array}$ & $\begin{array}{c}\text { OPC/ } \\
\text { BOS / } \\
\text { ROSA }\end{array}$ & $\begin{array}{c}\text { OPC/ } \\
\text { BOS }\end{array}$ & $\begin{array}{c}\text { OPC/ } \\
\text { BOS / } \\
\text { BPD }\end{array}$ \\
\hline $\mathrm{SiO} 2$ & 23.66 & 16.39 & 20.91 & 15.54 & 14.70 \\
\hline $\mathrm{TiO} 2$ & 0.50 & 0.38 & 0.50 & 0.42 & 0.41 \\
\hline $\mathrm{Al2O} 3$ & 7.13 & 3.76 & 6.59 & 3.42 & 3.25 \\
\hline $\mathrm{Fe} 2 \mathrm{O} 3$ & 6.32 & 5.81 & 5.46 & 10.36 & 11.20 \\
\hline $\mathrm{MnO}$ & 1.00 & 0.57 & 0.35 & 1.29 & 1.44 \\
\hline $\mathrm{MgO}$ & 5.08 & 2.00 & 2.09 & 3.37 & 3.69 \\
\hline $\mathrm{CaO}$ & 45.27 & 54.73 & 49.07 & 50.65 & 48.76 \\
\hline $\mathrm{Na} 2 \mathrm{O}$ & 0.22 & 0.16 & 0.19 & 0.13 & 0.16 \\
\hline $\mathrm{K} 2 \mathrm{O}$ & 0.40 & 0.43 & 0.57 & 0.32 & 0.44 \\
\hline $\mathrm{P} 2 \mathrm{O} 5$ & 0.32 & 0.29 & 0.33 & 0.53 & 0.57 \\
\hline $\mathrm{SO} 3$ & 1.35 & 4.15 & 2.16 & 1.67 & 1.43 \\
\hline Lol & 8.49 & 10.40 & 11.41 & 11.56 & 13.24 \\
\hline Total & 99.75 & 99.06 & 99.62 & 99.27 & 99.28 \\
\hline
\end{tabular}

\subsection{Density results}


The average measured densities of paving blocks that were made are presented in table 4. It can be seen that the densities for different groups change significantly due to the different specific gravities of the ingredients in each mix. The density ranges between approximately 2000 to $2300 \mathrm{~kg} / \mathrm{m}^{3}$ as expected.

Table 4. Density results for all paste mixes.

\begin{tabular}{|l|c|l|c|}
\hline Mix code & $\begin{array}{c}\text { Density } \\
\left(\mathrm{Kg} / \mathrm{m}^{3}\right)\end{array}$ & \multicolumn{1}{|c|}{ Mix code } & $\begin{array}{c}\text { Density } \\
\left(\mathrm{Kg} / \mathrm{m}^{3}\right)\end{array}$ \\
\hline OPC40/BOS30/GGBS30 & 2191 & OPC50/BOS30/ROSA20 & 2217 \\
\hline OPC30/BOS30/GGBS40 & 2120 & OPC52/BOS18/ROSA30 & 2052 \\
\hline OPC30/BOS40/GGBS30 & 2238 & OPC60/BOS20/ROSA20 & 2125 \\
\hline OPC30/BOS35/GGBS35 & 2181 & OPC70/BOS15/ROSA15 & 2133 \\
\hline OPC20/BOS40/GGBS40 & 2177 & OPC70/BOS30 & 2322 \\
\hline OPC20/BOS50/GGBS30 & 2270 & OPC60/BOS40 & 2338 \\
\hline OPC30/BOS65/PG5 & 2395 & OPC50/BOS50 & 2387 \\
\hline OPC40/BOS55/PG5 & 2354 & OPC40/BOS60 & 2370 \\
\hline OPC50/BOS45/PG5 & 2346 & OPC30/BOS70 & 2393 \\
\hline OPC60/BOS35/PG5 & 2261 & OPC80/BOS10/BPD10 & 2197 \\
\hline OPC70/BOS25/PG5 & 2208 & OPC70/BOS20/BPD10 & 2263 \\
\hline OPC50/BOS47/PG3 & 2392 & OPC60/BOS33/BPD7 & 2296 \\
\hline OPC30/BOS35/ROSA35 & 2030 & OPC50/BOS45/BPD5 & 2327 \\
\hline OPC40/BOS30/ROSA30 & 2043 & OPC40/BOS55/BPD5 & 2366 \\
\hline OPC50/BOS25/ROSA25 & 2084 & & \\
\cline { 1 - 2 }
\end{tabular}

\subsection{Strength results and discussion}

Five groups of binary and ternary mixtures were designed with different proportions as shown in figures 1 to 5 .

The use of BOS with mixtures of OPC/BOS/GGBS, OPC/BOS/PG, OPC/BOS and OPC/BOS/BPD to produce paving blocks confirmed that up to 70 percent of cement replacement can be achieved and the result was higher than the minimum requirements and the reason is due to the pozzolanic properties of the BOS.

Furthermore, figure 1 shows that the use of up to $40 \%$ basic oxygen slag and up to $40 \%$ ground granulated blast furnance slag as a replacement for cement shows sufficient strength after 28 days in the split tensile strength, the results also confirmed that it is possible to reduce cement by up to $80 \%$. Moreover, it can be seen that the maximum split tensile strength can be achieved by using $50 \%$ BOS, $30 \%$ GGBS, and $20 \%$ OPC at 28 days.

On other hand, using 5\% plasterboard gypsum in combination with OPC/BOS/PG as a partial replacement of cement showed satisfactory results for use as paving blocks as shown in figure 2. 
Dunsterr, (2008) showed that the addition of gypsum at quantities greater than $5 \% \mathrm{SO}_{3}$ (by weight of cement) to such cements (which contain calcium aluminate and calcium silicate hydrates) leads to a high risk of durability problems. This is because the excess sulfate reacts with the silicates and aluminates in the cement to form large amounts of expansive products, such as ettringite. Therefore, a maximum PG content of 5 percent was used in this investigation. Furthermore, the results of ternary mix of OPC/BOS/ROSA paste are shown in figure 3 and the use of up to $35 \%$ basic oxygen slag and up to $35 \%$ run of station ash as a replacement for cement shows sufficient strength after 14 days in the split tensile strength according to the requirements. Moreover, it can be seen that the split tensile strength of $5.1 \mathrm{MPa}$ is achieved by the optimum ternary mix 18\% BOS, 30\% ROSA, and 52\% OPC at 28 days.

The results of binary BOS and OPC in Figure 4 show that $40 \%$ BOS and 60\% OPC produces the highest strength. Moreover, it can be seen that the maximum split tensile strength can be achieved by using 55\% BOS, 5\% BPD, and 40\% OPC at 14 days as shown in figure 5 and the results also confirmed that it is possible to reduce cement by up to $60 \%$.

In general, BOS typically hydrates after mixing with Portland cement or other alkali materials, such as; BPD which provides a source of alkalinity with which the slag reacts to form cement hydration products. The excessive amount of alkali in the system has a detrimental effect on the hydration of alkali activated slag causing low strength and a delay in setting.

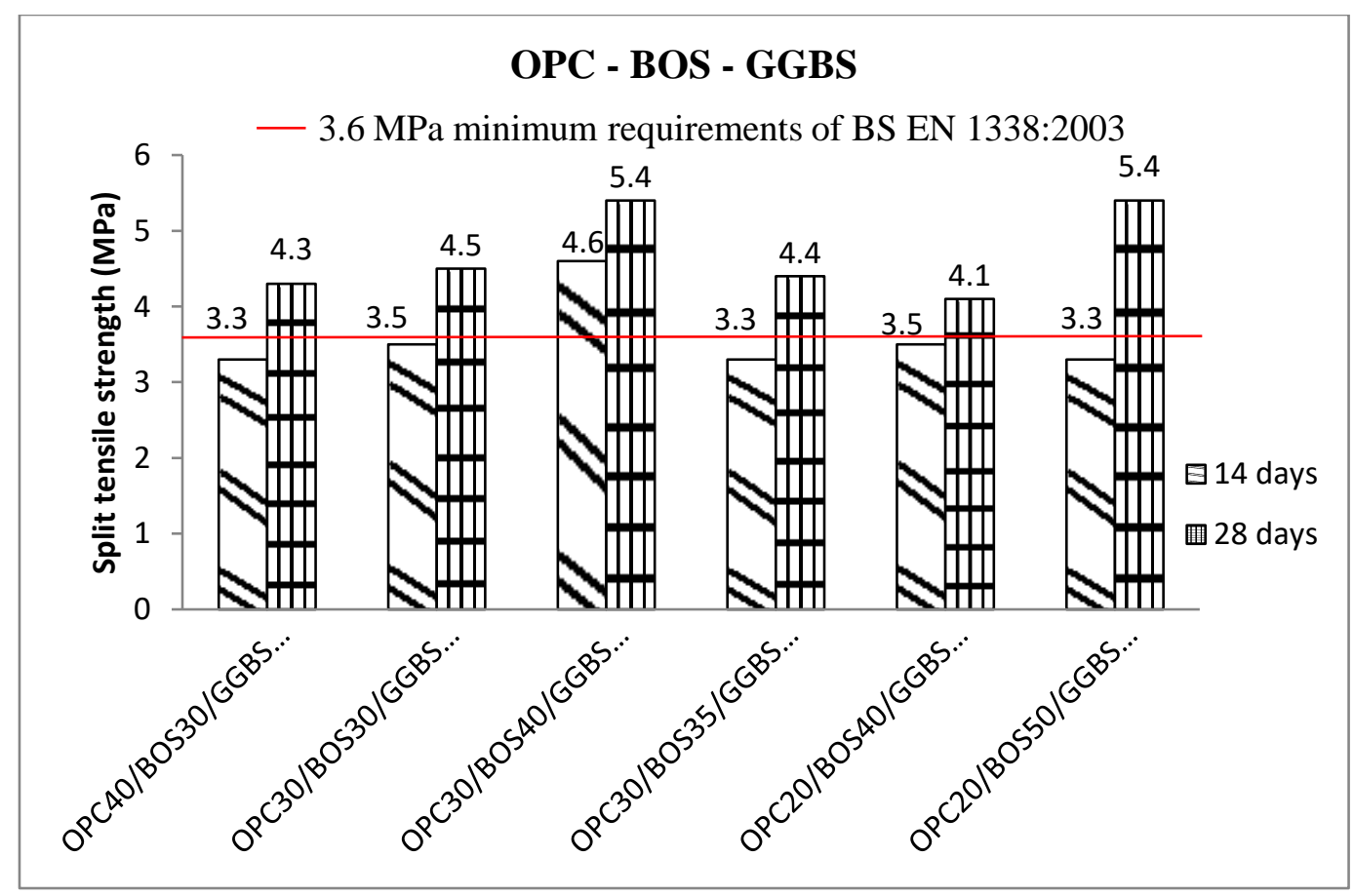

Figure 1. Split tensile strength (MPa) of blocks at 14 and 28 days 


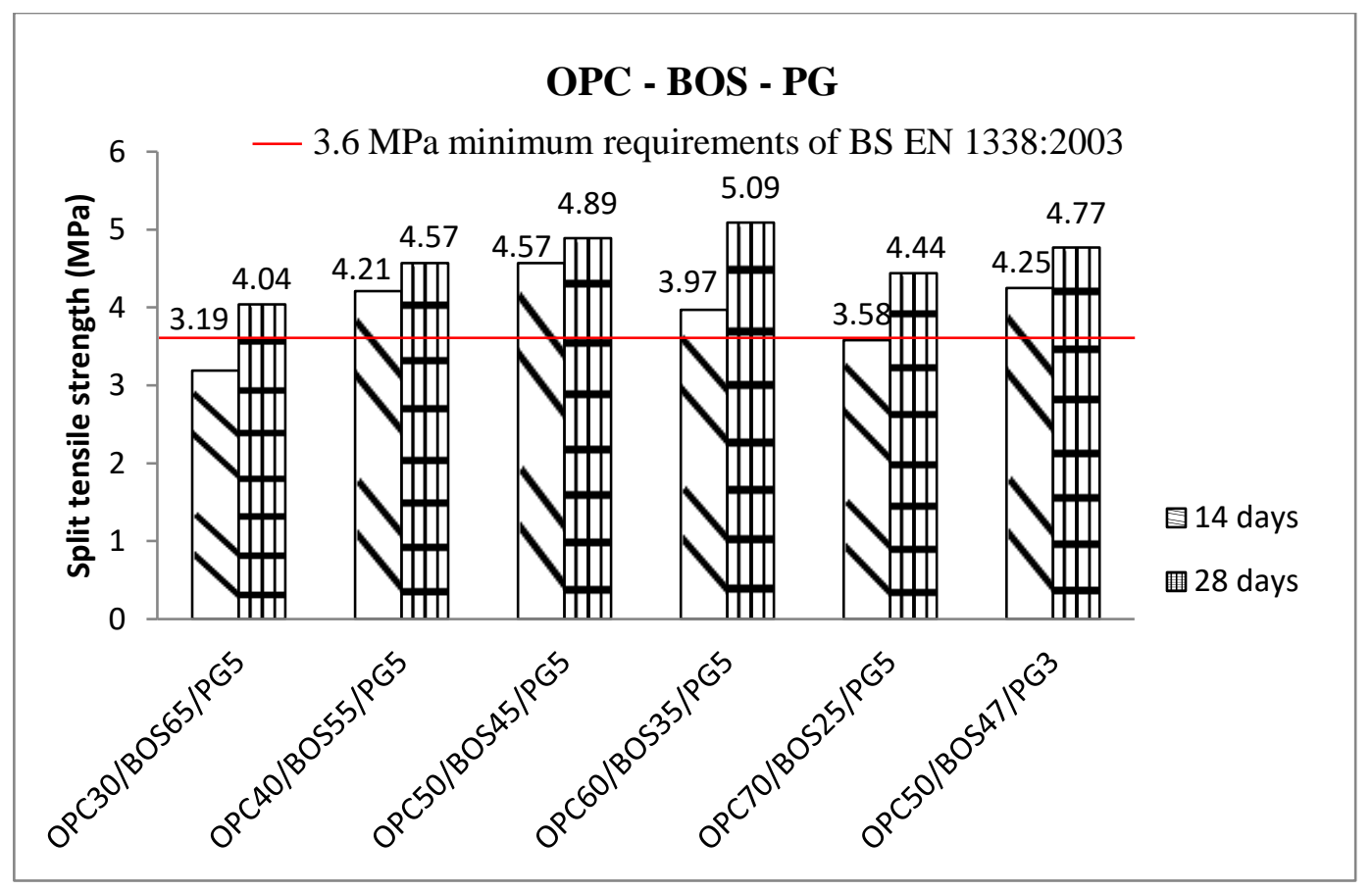

Figure 2. Split tensile strength (MPa) of blocks at 14 and 28 days

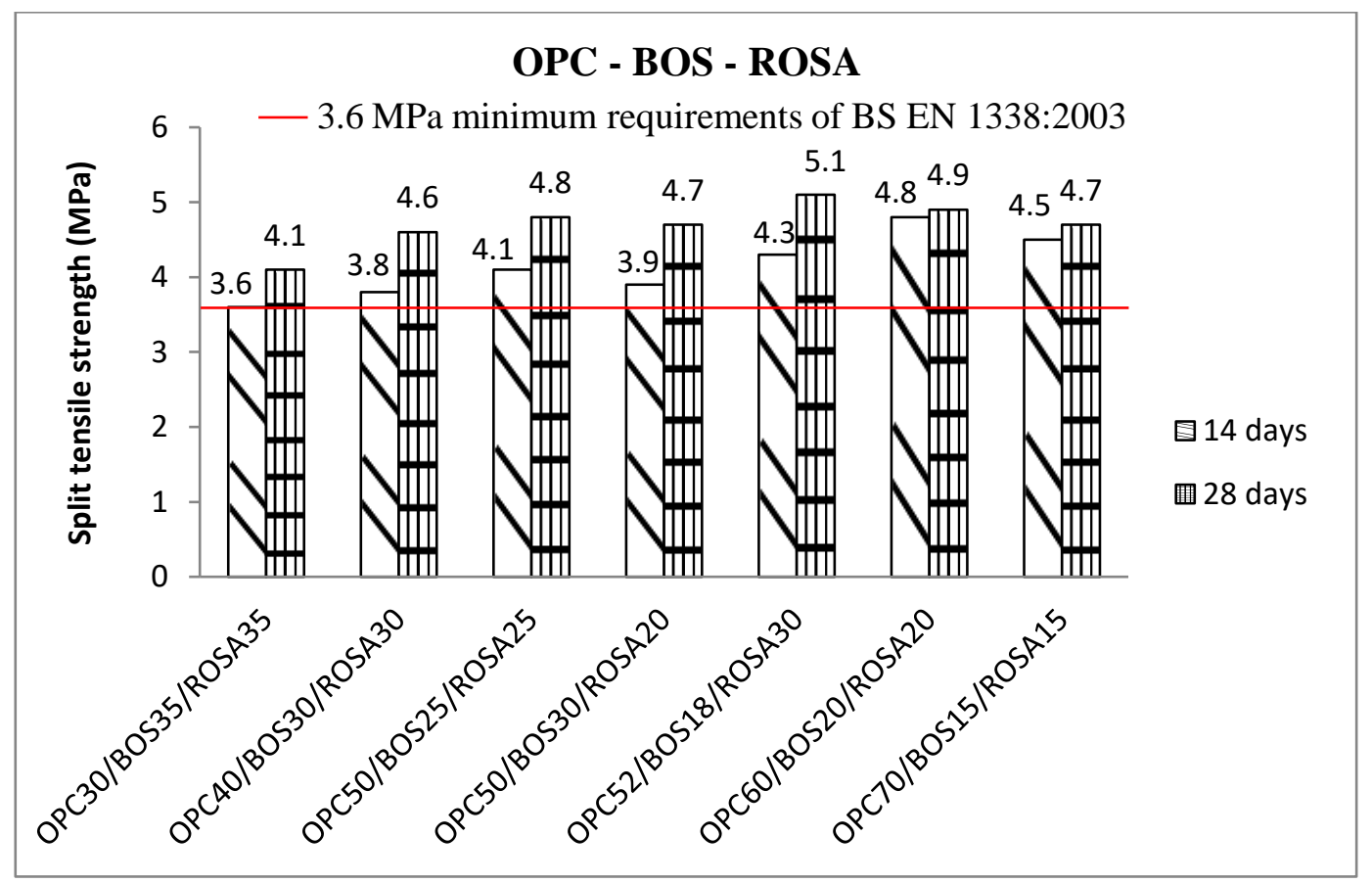

Figure 3. Split tensile strength (MPa) of blocks at 14 and 28 days 


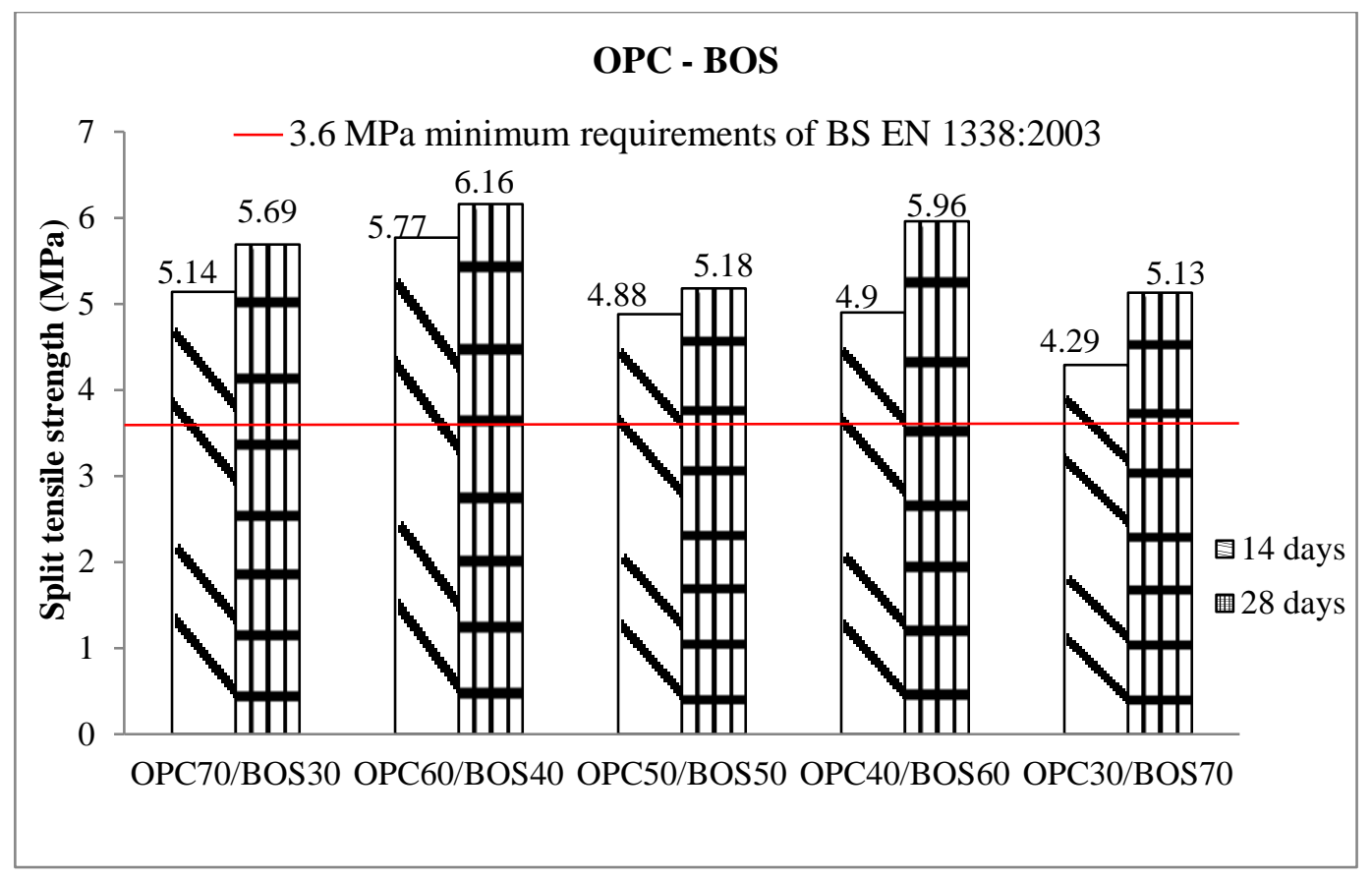

Figure 4. Split tensile strength (MPa) of blocks at 14 and 28 days

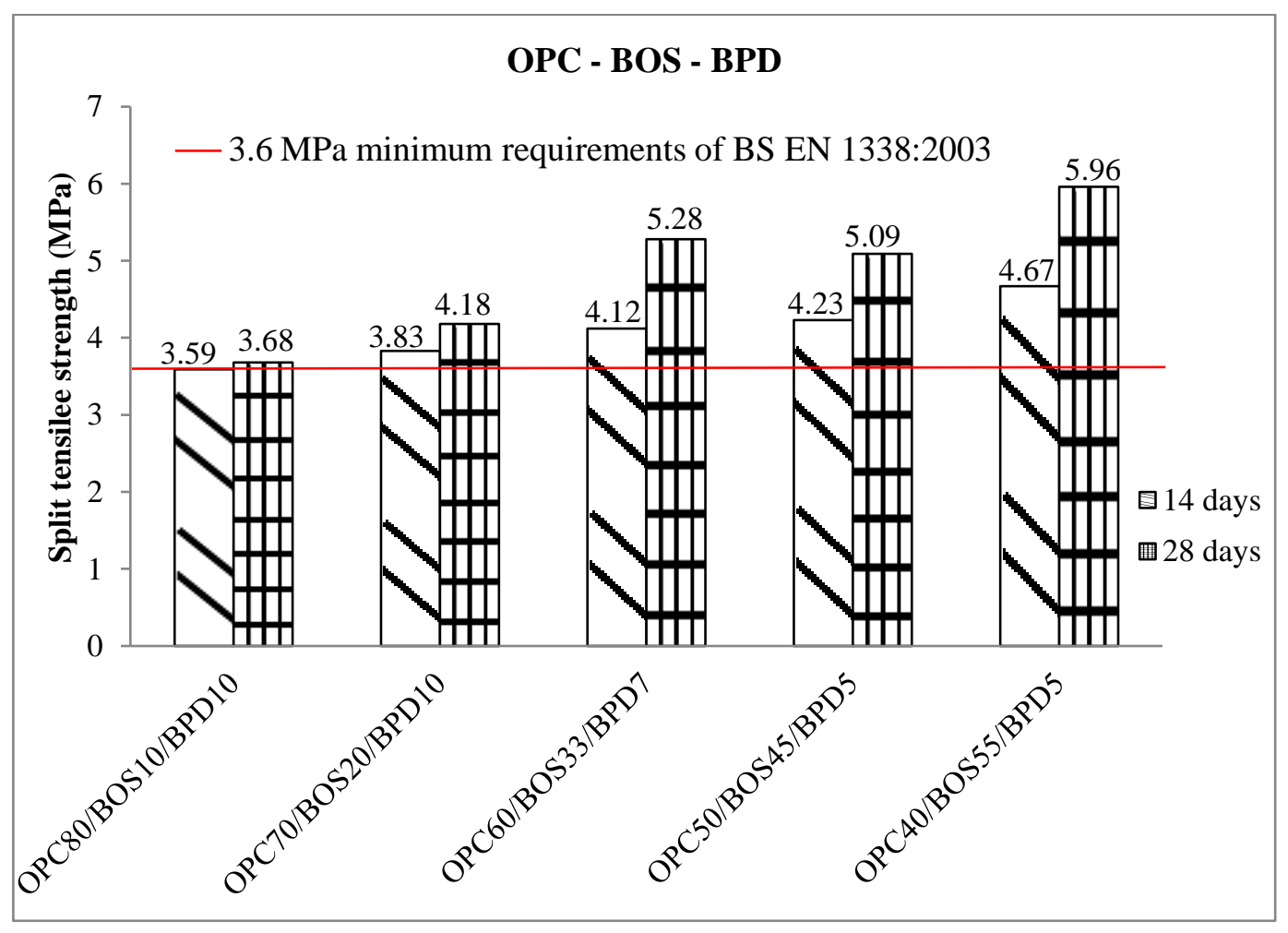

Figure 5. Split tensile strength (MPa) of blocks at 14 and 28 days 


\section{CONCLUSIONS}

The following conclusions can be drawn from this study:

1) Paving blocks could be successfully made using cement and waste minerals such as basic oxygen slag (BOS), ground granulated blast furnace slag (GGBS), run-of-station ash (ROSA), plasterboard gypsum (PG), and cement by pass dust (BPD) to achieve the required strength for paving blocks.

2) The results show that the ternary materials such as basic oxygen slag (BOS), ground granulated blast furnance slag (GGBS), run-of-station ash (ROSA) were more effective to reduce cement content.

3) Up to 80 percent replacement of Portland cement can be achieved in binders and this can lead to reduced cement contents for production of paving blocks in accordance to the BS EN 1338:2003.

4) It is possible to use waste minerals to achieve the minimum required split tensile strength of 3.6 MPa for paving blocks in accordance to the British Standard BS BN1338: 2003.

5) Results show that BOS up to $70 \%$, GGBS up to $40 \%$, ROSA up to $35 \%$, BPD up to $10 \%$, and PG up to $5 \%$ by weight can replace the Portland cement without negative impacts on their desirable properties in accordance to the BS EN 1338: 2003.

\section{REFERENCES}

Andrew M Dunster, (2008). "Recycled gypsum in concrete construction product applications", Waste and Resources Action Program (WRAP) BRE.

American Concrete Institute, Farmington Hills, Mich. (2003). "Slag Cement in Concrete and Mortar", Report of ACI Committee; 233, ACI 233R-03.

Beaty, A. N. S., and Raymond, G. P. (1995). “Concrete Block Road Paving”, Concrete Int. Vol 17(5), pp 36-41.

BS EN197-1, BSI. (2011). “Cement, part 1: composition, specifications and conformity criteria for common cement".

BS EN 15167-2:2006: (2006). "Specification for ground granulated blast furnace slag for use with Portland cement”, British Standard Institute, London. 
BS EN 1338. (2003). "Concrete paving blocks requirements and test methods", British Standard Institute, London.

Dubey, A., Chandak, R. and Yadav, R.K. (2012). "Effect of blast furnace slag powder on compressive strength of concrete", International Journal of Scientific \& Engineering Research, Volume 3, Issue 8.

Ganjian, E., Jalull, G., and Sadeghi-Pouya, H. (2015). "Reducing cement contents of paving blocks by using mineral waste and by-product materials.", Journal of Materials in Civil Engineering- ASCE, Vol. 27, issue 1, pp 04014106-1 to 04014106-11, 10.1061/(ASCE)MT.1943-5533.0001037, ISSN 0899-1561.

Ganjian, E, Sadeghi-Pouya, H. (2009). "Investigation on the use of industrial and constructiondemolition wastes as cement replacement in concrete paving blocks", ' In ConMat'09 - '4th International Conference on Construction Materials: Performance, Innovations and Structural Implications', S 6-2-3, Nagoya, Japan: 295-300.

Ganjian, E., Jalull, G., and Sadeghi-Pouya, H., (2015). "Using waste materials and by-products to produce concrete paving blocks", Construction and Building Materials, Vol. 77, pp. 270275.

Jalull, G, Ganjian, E and Sadeghi-Pouya, H, (2014). "Using GGBS and mineral wastes to reduce cement in paving block", Institution of Civil Engineering Construction Materials journal (ICE Proceedings), Volume 167, Issue CM2, pp 91-103.

Limbachiya, V. Ganjian, E and Claisse, P. (2006). "Strength, durability and leaching properties of concrete paving blocks incorporating GGBS and SF", Construction and Building Materials, Vol. 113, pp 273-279, ISSN: 0950-0618) DOI:10.1016/j. conbuildmat. 2016.02.152.

Oss, H. G. V. (2003). "Slag Iron and Steel, U.S. Geological Survey Minerals Yearbook." USGS, 2011. Mineral Commodity Summaries. U.S. Geological Survey.

Olivier, J., Janssens-Maenhout, G. and Peters, J. (2012). "Trends in global CO2 emissions". PBL Netherlands Environmental Assessment Agency. 
Turanli, L, Uzal, B, and Bektas.F. (2004). "Effect of material characteristics on the properties of blended cements containing high volumes of natural pozzolans", Cement and Concrete Research, 34, 2277-2282. 